\title{
Water Resource Monitoring and Assessment for Madurai District, Tamil Nadu, India
}

\author{
Shafiullah. $\mathrm{G}^{1}$, Suhatharahima Siraj ${ }^{2}$, Rajani. $\mathrm{R}^{2}$ \\ ${ }^{I}$ Department of Earth and Environmental Sciences, Kuwait University, Kuwait \\ ${ }^{2}$ Department of Geology, Alagappa Government Arts College, Karaikudi, Tamil Nadu, India
}

\begin{abstract}
The surface water bodies and ground water resources of Madurai district, Tamil Nadu, India were monitored for the last 45 years. The surface waterbodies were derived from toposheet and satellite images for 1970,1990, 2001, 2010 \& 2014 years. The changes in surface waterbodies were discussed in this paper. Most of the surface waterbodies were silted and dumped by the wastages in recent years. Many water bodies were transformed as other land use. Few water bodies were still serving to the environment in terms of storage and supply.
\end{abstract}

Keywords: Surface Waterbodies, NDWI, MNDWI, GIS.

\section{Introduction}

Surface water bodies and ground water reserves are the driving forces for all lives. Depleting water resources is one of the major impact of climate change. Changes in terrain temperature and rainfall have important implications for all aspects of the hydrologic cycle. Because, variations in these parameters determine the amount of water that infiltrates the surface, evaporates or transpires back to the atmosphere, becomes stored as groundwater. The storage of ground water quantity and quality are greatly controlled by the geology and subsurface structures.

The over exploitation of ground water is a great cause of declining water resources. The water management technologies are serving the society to recover from scarcity and renew the water resources. The rainfall and infiltration are regulating the recharge of ground water. Hence, the land use has more responsibility for ground water recharge. Remote sensing data provide huge information for monitoring water features and wetlands. The near infra-red and middle infra-red bands retrieve more water information from space. The NDWI (Normalised Difference Water Index) is the index used to delineate the open surface water features and produce thematic maps for the water resource assessment. NDWI is calculated using the band ratio of green and near infra-red band.

\section{Study Area}

Madurai district was divided into Madurai and Theni districts in 1996 and retained Madurai as its headquarters. The district lies between $77^{\circ} 00^{\prime \prime}$ and $78^{\circ} 30^{\prime \prime}$ of the eastern longitude and between $9^{\circ} 30^{\prime \prime}$ and $10^{\circ}$ 30 " of the northern latitude. It has an area of $3741.73 \mathrm{Km}^{2}$ and is bounded on the west by Theni district, on the north by Dindigul district, on the east by Sivagangai district and on the south by Virudhunagar district. (Fig. 1)

\section{Normalised Difference Water Index (Ndwi)}

Remote sensing data provide huge information for monitoring water features and wetlands. The near infra-red and middle infra-red bands retrieve more water information from space. The NDWI (Normalised Difference Water Index) is the index used to delineate the open surface water features and produce thematic maps for the water resource assessment. NDWI is calculated using the band ratio of green and near infra-red band. The built up land produces noises over the water features, and it will reduced by using Middle infra-red band instead of near infra-red band. This is called MNDWI (Modified Normalised Difference Water Index). The water bodies have +1 pixel value. The other pixels having a range of values based on the wetness of the objects. The NDWI and MNDWI calibration were carried out for the 1976, 1991, 2001, 2010 and 2014 images. The water features were extracted, and thematic maps were prepared for all images. The area of water features in each image was calculated and analysed.

The survey of India Toposheets were registered and the water bodies were digitised (Fig.1) and these result was taken as a base information. The water features were extracted from 1991, 2001, 2003, 2010 and 2014 images and the total area were calculated and mentioned in Table 1.

All water bodies were marked in toposheet and the area of water bodies was $221 \mathrm{~km}^{2}$. The water features were identified from MNDVI of different images (Fig.2-11) In 1991 image, MNDWI results stated that $51.24 \mathrm{~km}^{2}$ of area was filled by water. The rainfall and the water inlets have been decided the surface water storage. The water features were decreased to $50.16 \mathrm{~km}^{2}$ in 2001 MNDWI image. During 2003, $13.56 \mathrm{~km}^{2}$ area of water features were extracted. There was a huge reduction in area of water features. MNDWI of 2010 image show the $16.40 \mathrm{~km}^{2}$ of water bodies and it greatly reduced to $15.31 \mathrm{~km}^{2}$ in 2014 MNDWI results. The great reduction in surface water features were noticed from the results. The study 
area possesses good drainage system and approximately 4000 tanks. Many channels and check dams also constructed in the district. The water flows in the channels and rivers were dry in recent years. Due to urbanization the water inlets to the water bodies were shrunk and dumped by domestic effluents. Many water bodies were silted and filled with water plants. Many surface water bodies also disappeared and urbanized.

Table.1. Area of Water Features

\begin{tabular}{|c|c|c|c|c|c|c|}
\hline Water Features & $\begin{array}{c}1970 \\
\text { Toposheet Data }\end{array}$ & 1990 & 2001 & 2003 & 2010 & 2014 \\
\cline { 1 - 7 } NDWI & \multirow{2}{*}{221} & 60.17 & 63.37 & 13.56 & 17.18 & 14.27 \\
\cline { 1 - 6 } & & 51.24 & 50.16 & 15.47 & 16.40 & 15.31 \\
\hline
\end{tabular}

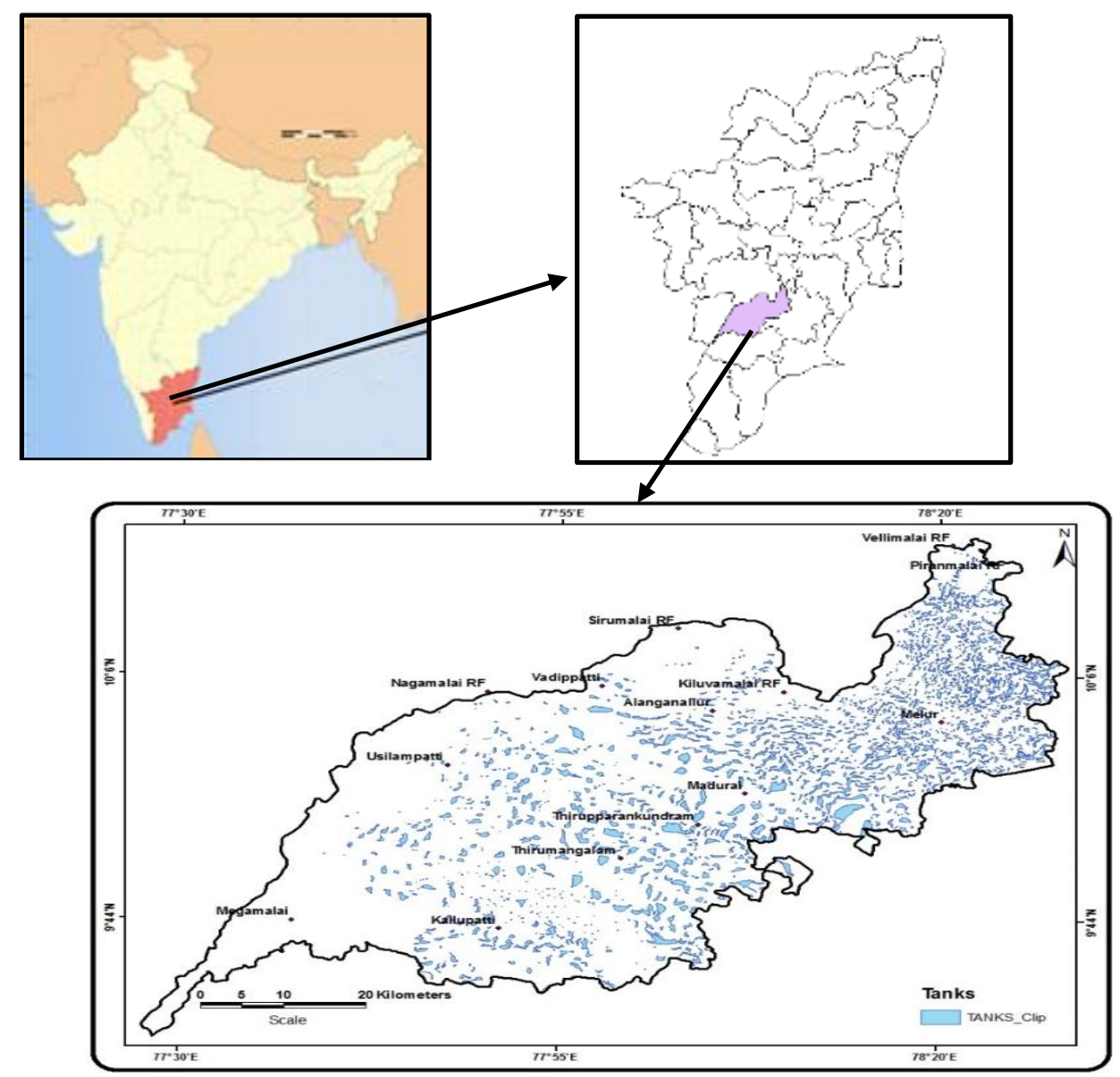

Fig. 1. Study Area - Surface Waterbody Map

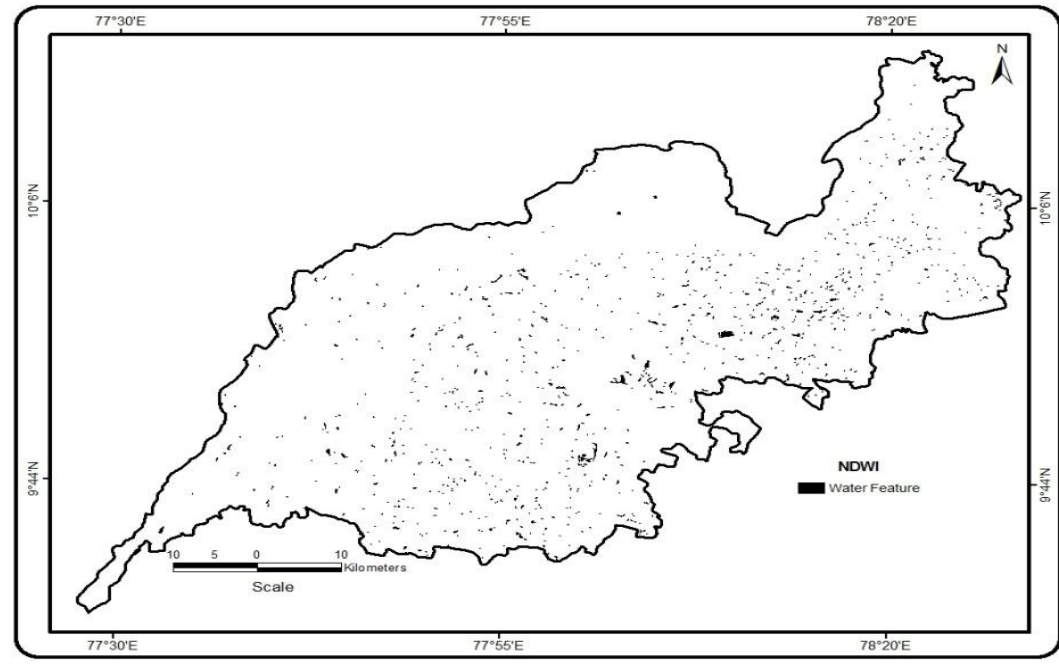

Fig. 2. NDWI Water Features _ 1991 


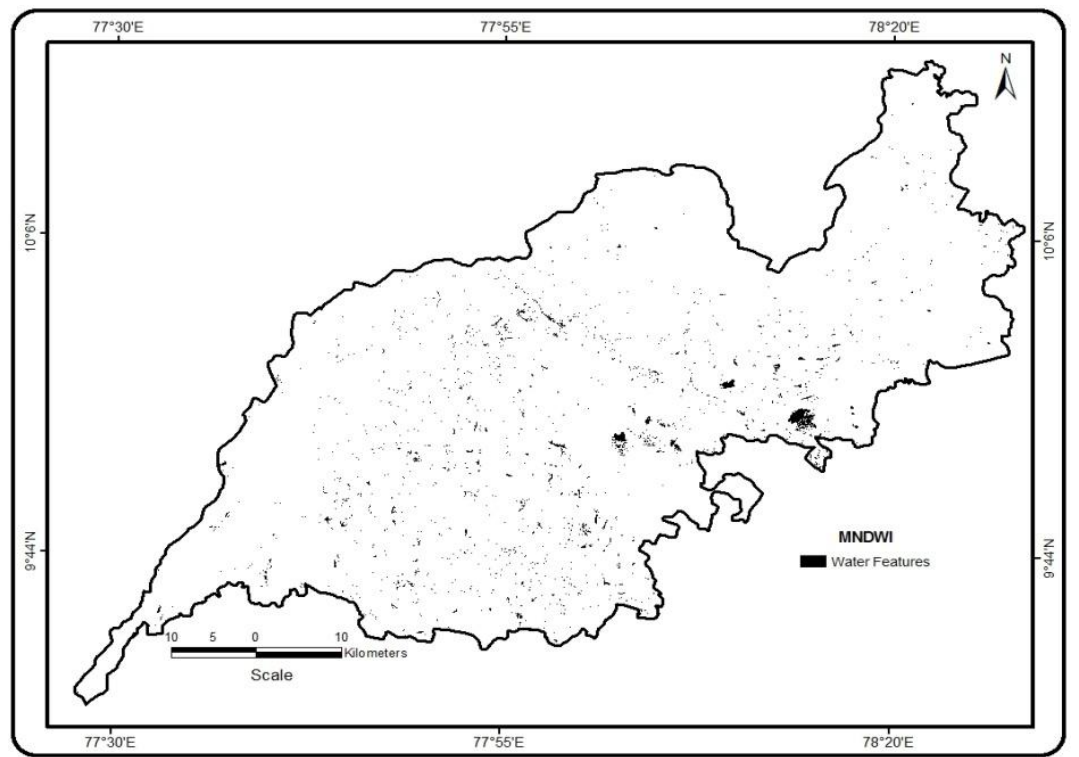

Fig. 3. MNDWI Water Features _ 1991

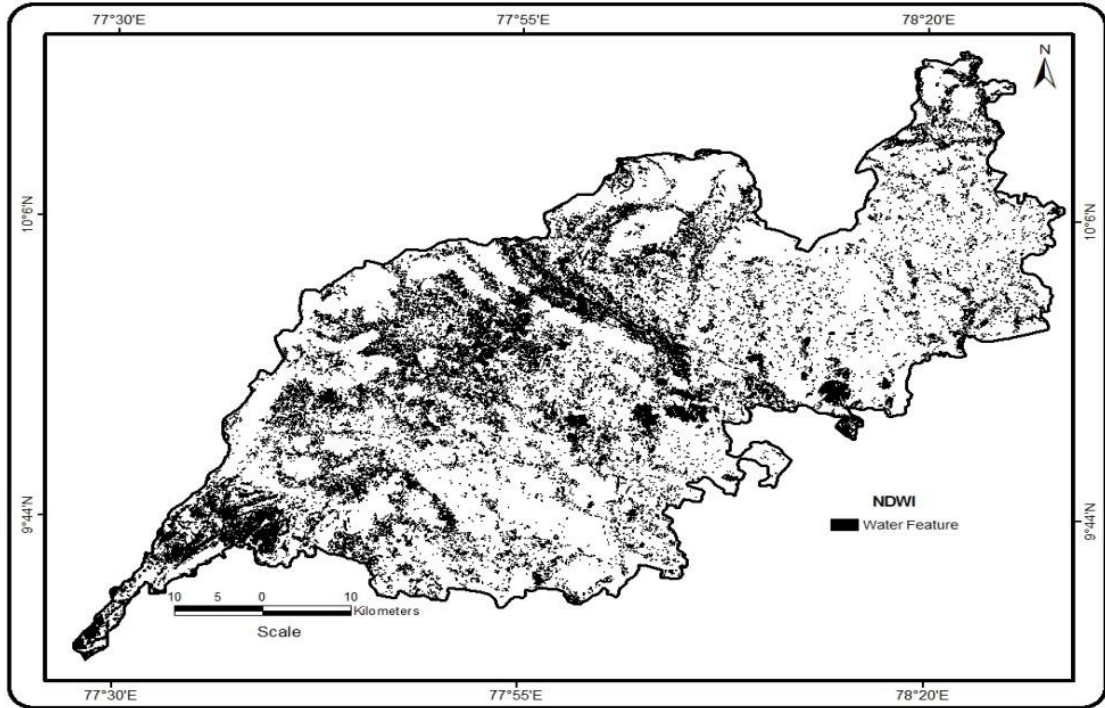

Fig. 4. NDWI Water Features _ 2001

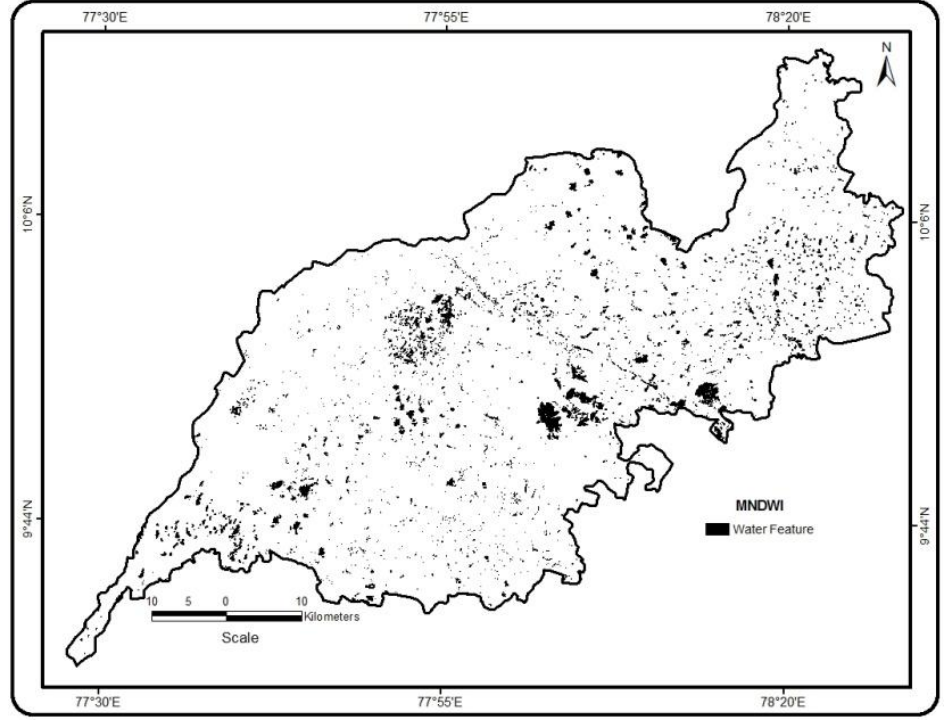

Fig. 5. MNDWI Water Features_ 2001 


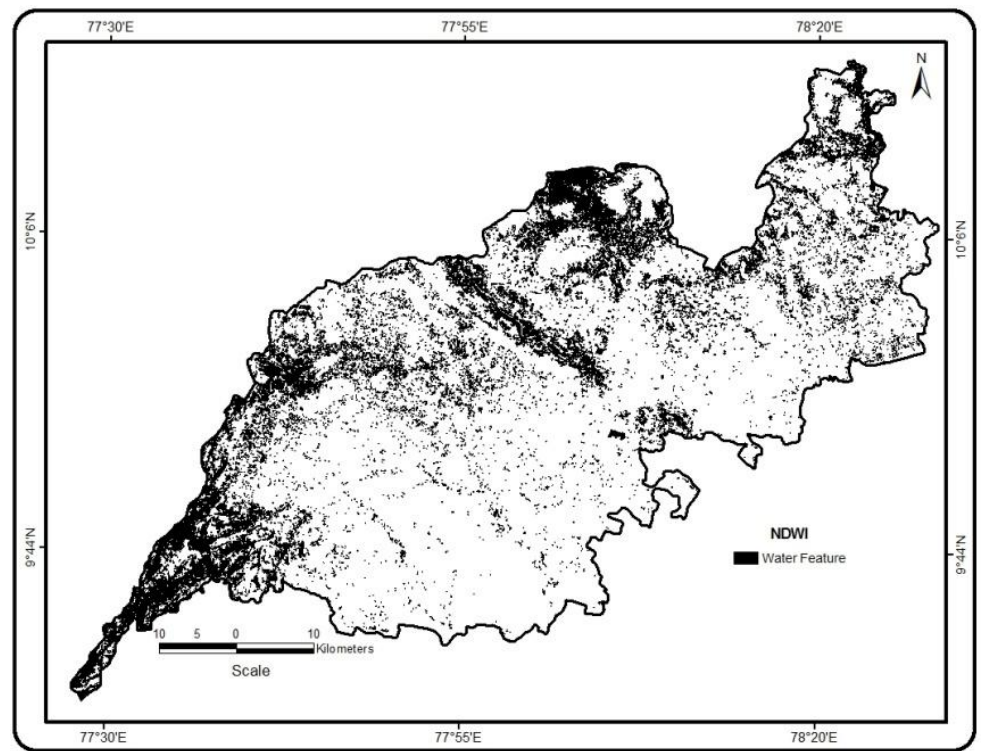

Fig. 6. NDWI Water Features _ 2003

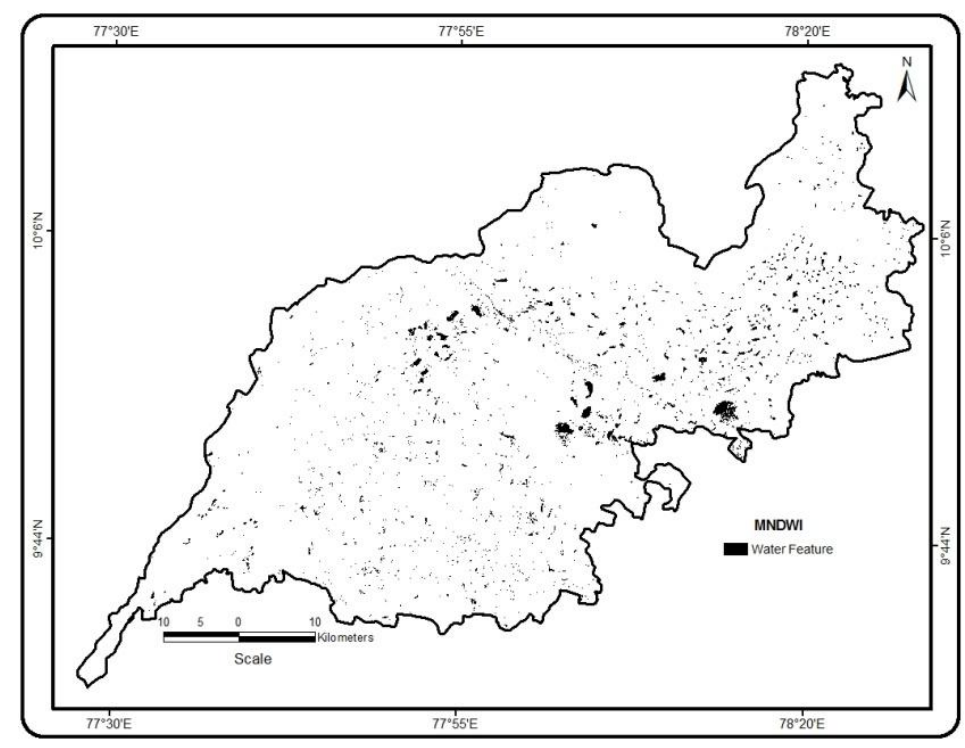

Fig. 7. MNDWI Water Features _ 2003

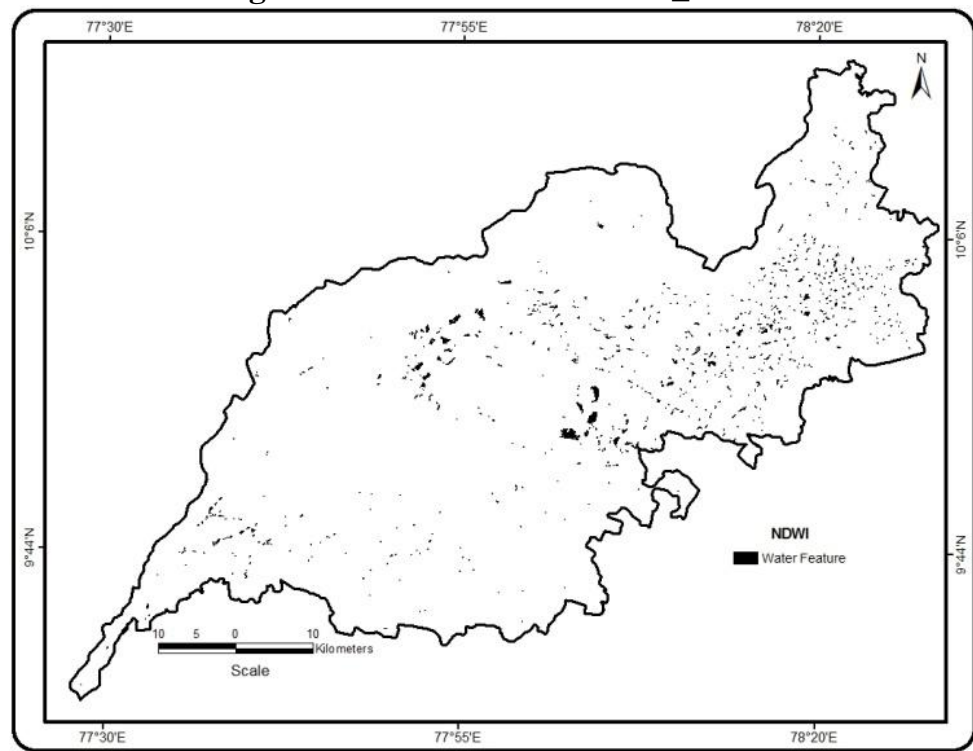

Fig. 8. NDWI Water Features_ 2010 


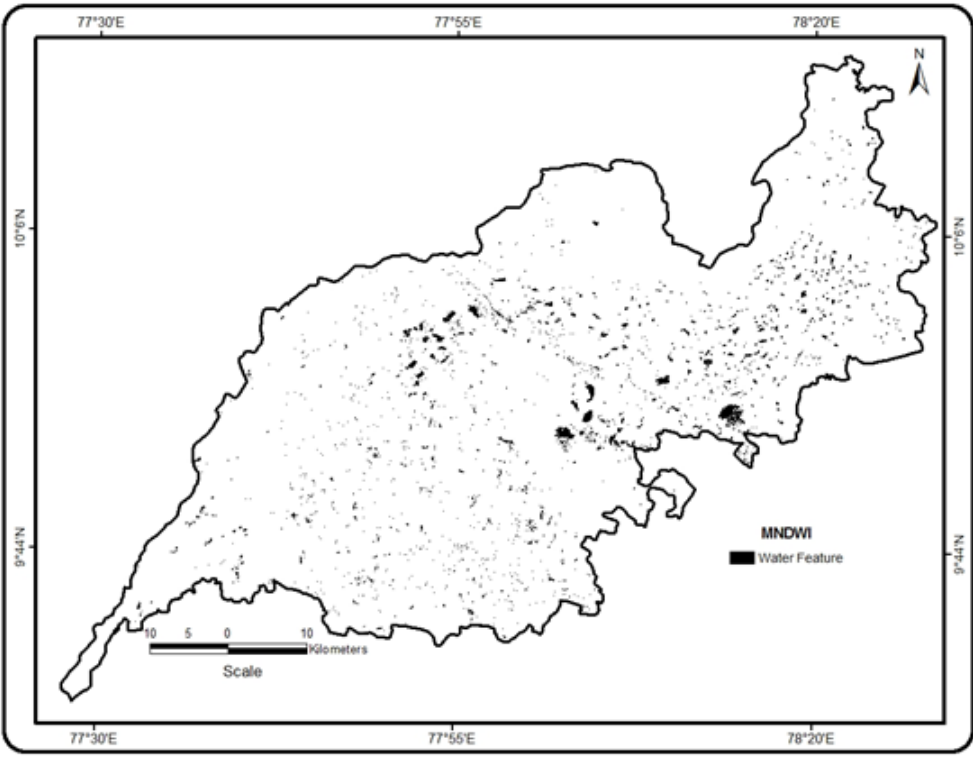

Fig. 9. MNDWI Water Features _ 2010

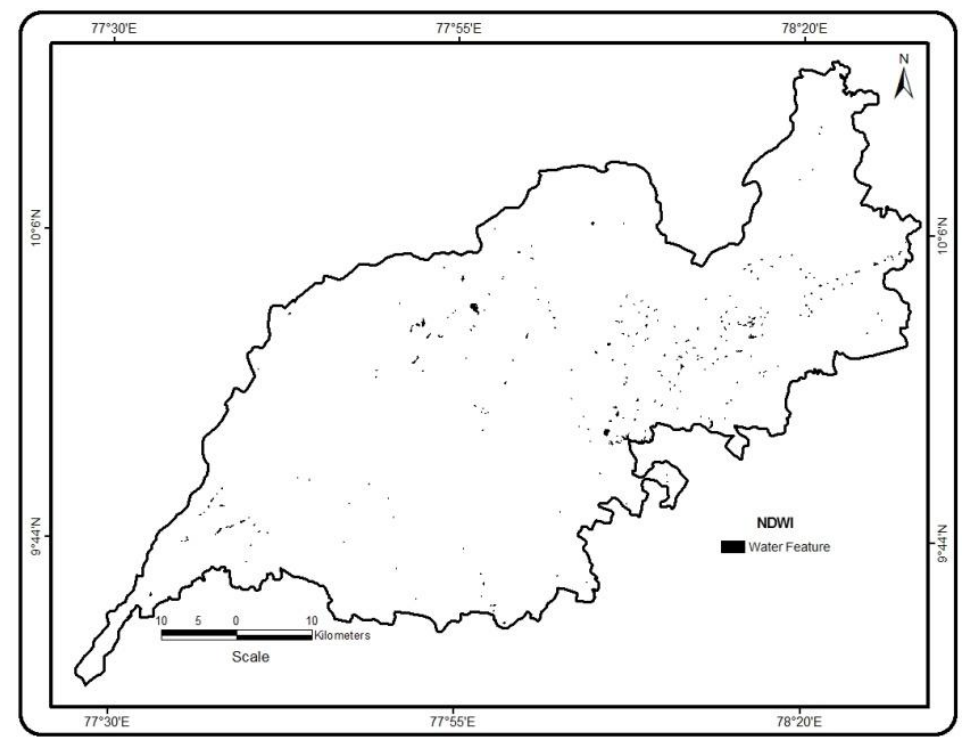

Fig. 10. NDWI Water Features_ 2014

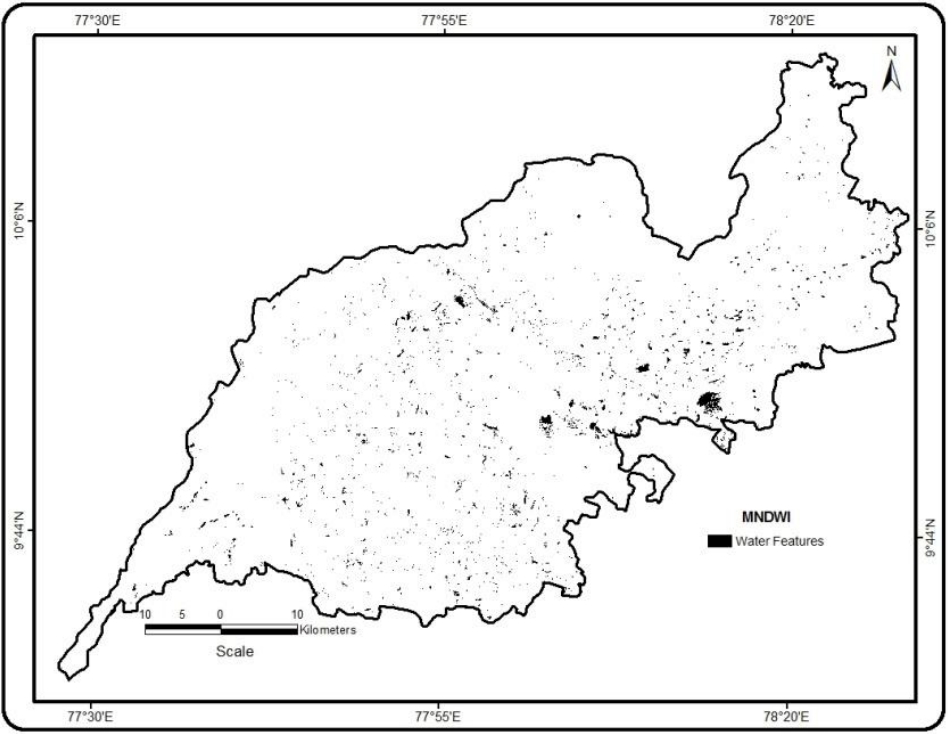

Fig. 11. MNDWI Water Features _ 2014 


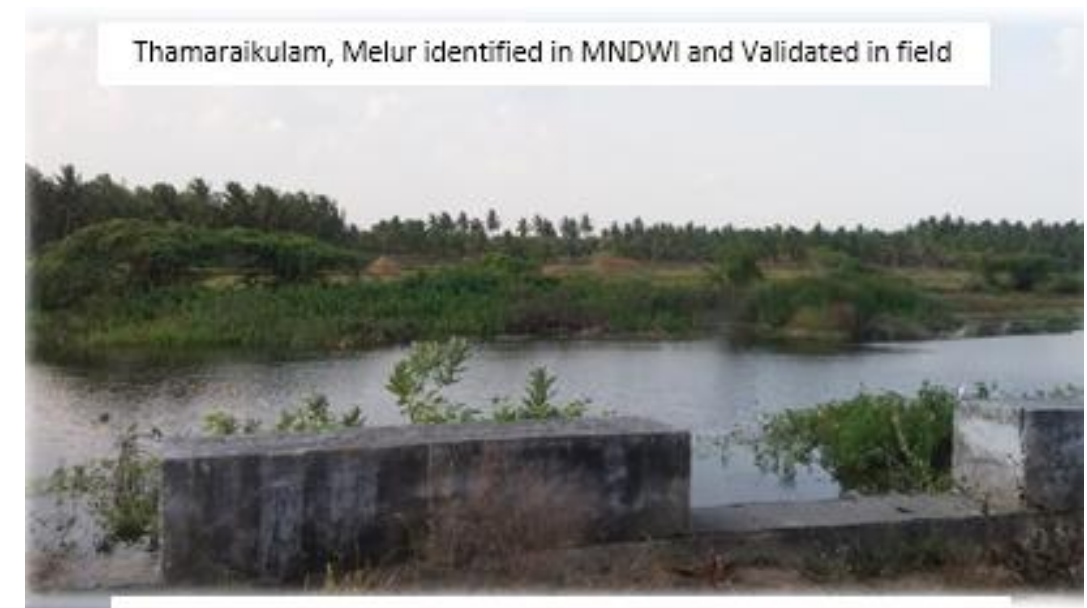

Pond near Alagar Kovil identified in MNDWI and Validated in field
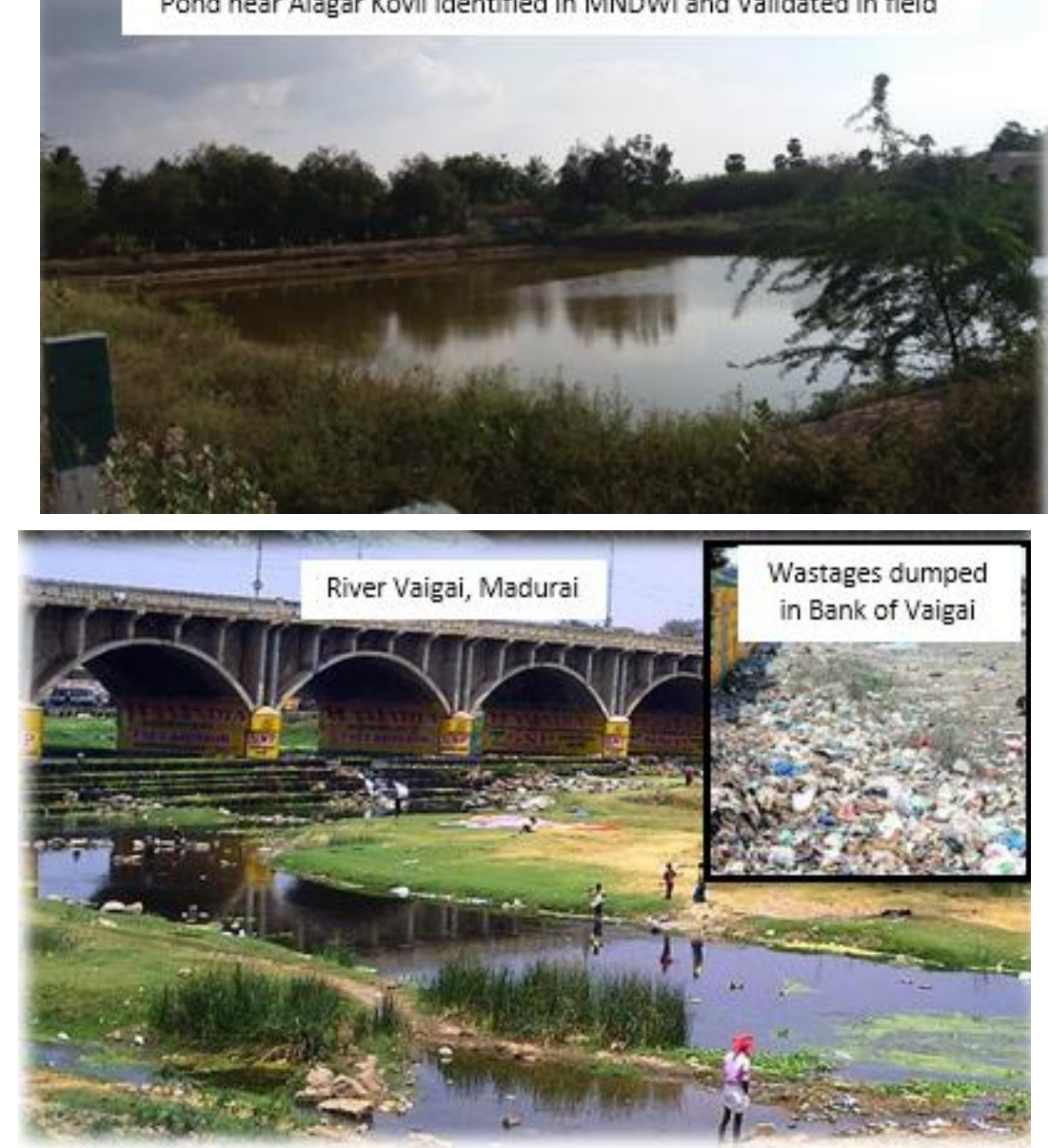

The precisions of NDWI and MNDWI of the images were compared. The water features have positive value both in NDWI and MNDWI. Zhongshiet al. (2013) have proposed NDWI water extraction method for natural disaster monitoring and environmental change studies. Ji et al. (2009) also suggest NDWI for mapping water bodies. NDWI and soil moisture have a major role in annual surface water balance in the environment (Gentineet al. 2012).Many researchers have suggested the NDWI method for information extraction with accurate boundaries of water bodies. (Li and Narayanan 2004; Jimenez et al. 2005; Myint 2008). Dorigoet al. (2012) have extracted NDMI from different satellite images, which had given promising results in terms of temporal, spatial resolution and land coverage. NDMI is being controlled by surface water balance, vegetation and LULC (Dorigoet al. 2012).

The modification of the NDWI using a MIR band instead of a NIR band canconsiderably improve the enhancement of open water features. It can quickly andaccurately discriminate water from non-water features. 
The MNDWI is moresuitable for enhancement of water with many built-up land areas in the backgroundthan the NDWI because it can efficiently reduce and even remove built-up landnoise. The threshold values for the MNDWI to achieve best water extraction resultare usually much less than those of the NDWI, suggesting using zero as a defaultthreshold value can produce better water extraction accuracy for the MNDWI thanfor the NDWI. This would be very useful for the MNDWI to be automated.The buildup noises were suppressed in MNDWI and it show zero threshold value. The accuracy assessments were also carried out for NDWI and MNDWI images. The overall accuracy for NDWI is $77.25 \%$ and MNDWI is $99.85 \%$. The kappa value of MNDWI is 0.9927 and no built-up land was mixed with water features.

\section{Conclusion}

The surface water bodies were silted and dumped by the wastages in recent years. Many water bodies were transformed as other land use. Few water bodies were still serving to the environment in terms of storage and supply. 1970 toposheet data shown that $221 \mathrm{~km}^{2}$ area were under water bodies. 1991 MNDWI data stated that $51.24 \mathrm{~km}^{2}$ area was filled with water. $50.16 \mathrm{~km}^{2}$ area was filled with water in 2001 . The 2003 image shows that $15.47 \mathrm{~km}^{2}$ area were water features. The area of surface water features were $16.40 \mathrm{~km}^{2}$ area and 5.31 $\mathrm{km}^{2}$ area in 2010 and 2014 images respectively.

\section{Acknowledgement}

The authors would like to thank the INSPIRE Division, Department of Science and Technology, Government of India, for financially supporting this research. The author thank reviewers for their suggestions and reviews.

\section{References}

[1] Dorigo, W., De Jeu, R., Chung, D., PArinussa, R., LiU, Y.,WAGNER, W. and FernándeZ-PriETO, D. (2012) Evaluating global trends (1988-2010) in harmonized multi-satellite surface soil moisture, Geophys. Res. Lett., v. 39, L18405.

[2] GENTINE, P., P. D’ODORICO, B. R. LINTNER, G. SIVANDRAN, and G. SALVUCCI (2012) Interdependence of climate, soil, and vegetation as constrained by the Budyko curve, Geophys. Res. Lett., v.39, L19404.

[3] JI, L., ZHANG, L. and WYLIE, B. (2009) Analysis of dynamic thresholds for the normalized difference water index. Photogramm. Eng. Remote Sens. v. 75(11), pp. 1307-1317.

[4] JIMENEZ, L.O., RIVERA-MEDINA, J.L., RODRIGUEZ-DIAZ, E., ARZUAGA-CRUZ, E., and RAMIREZ-VELEZ, M. (2005) Integration of spatial and spectral information by means of unsupervised extraction and classification for homogenous objects app. lied to multispectral and hyperspectral data. IEEE Transactions on Geoscience and Remote Sensing, v. 43, pp. 844-851.

[5] LI, J., and NARAYANAN, R. M. (2004) Integrated spectral and spatial information mining in remote sensing imagery. IEEE Transactions on Geoscience and Remote Sensing, v. 42, pp. 673-685.

[6] MYINT, S. W. (2008) An exploration of spatial dispersion, pattern, and association of socio-economic functional units in an urban system. App. lied Geography, v. 28, pp. 168-188.

[7] ZHONGSHI TANG, WENHAO OU, YUE DAI and YU XIN. (2013) Extraction of Water Body Based on Landsat TM5 Imagery A Case Study in the Yangtze River, Computer and Computing Technologies in Agriculture VI IFIP Advances in Information and Communication Technology, v.393, pp.416-420.

IOSR Journal of Applied Geology and Geophysics (IOSR-JAGG) is UGC approved Journal with Sl. No. 5021, Journal no. 49115.

Suhatharahima Siraj. "Water Resource Monitoringand Assessment for Madurai District, Tamil Nadu, India." IOSR Journal of Applied Geology and Geophysics (IOSR-JAGG) 5.4 (2017): 28-34. 